4. Козлов В. И. Индивидуально-типологические особенности микроциркуляции у человека / В. И. Козлов, Ф. Б. Литвин, М. В. Морозов // Biomed. Biosoc. Antropology. - 2007. - № 9. - С. 249-250.

5. Козлов В. И. Лазерная допплеровская флоуметрия в оценке состояния и расстройств микроциркуляции крови / В. И. Козлов, Г. А. Азизов. - М. : РУДН ГНЦ лазер. мед., 2012. - 32 с.

6. Решетнев В. Г. Индивидуальные показатели системы кровообращения / В. Г. Решетнев, Л. И. Глико. М. : Эко-Пресс, 2011. - 208 с.

7. Shoucri B. M. Plasma Stimulated Pseudopod Formation Is Increased In Patients With Elevated Blood Pressure / B. M. Shoucri, K. M. Edwards, G. W. Schmid-Schönbein, P. J. Mills // Hypertension Research Official Journal Of The Japanese Society Of Hypertension. - 2011. - V. 34 (6). - P. 96-101.

Станишевская Татьяна, Горная Оксана, Горбань Дарья. Особенности резистентности капиллярного кровотока у студентов при окклюзионной пробе. Экспериментальное исследование включало изучение функционального состояния микроциркуляции крови с помощью метода лазерной допплеровской флоуметрии (ЛДФ). Это позволяло оценить состояние тканевого кровотока и выявить индивидуально-типологические особенности микроциркуляции крови. Среди обследованных студентов установлено три типа ЛДФ-грамм, которые соответствуют разным типам микроциркуляции крови (нормоэмический, гиперэмический и гипоэмические). При исследовании индивидуально-типологических особенностей микроциркуляции крови у студентов 1722 лет проведена оценка функциональных резервов системы микрососудов. Резистентность капиллярного кровотока (РКК) на окклюзионную пробу у обследованных лиц зависела от различных типов микроциркуляции крови. Самая высокая степень резистентности при окклюзионной пробе была у обследованных лиц с гипоэмическим типом микроциркуляции крови $(415,65 \%)$. Резистентность капиллярного кровотока у студентов с нормоэмическим и гиперэмическим типами микроциркуляции крови была ниже по отношению к гипоэмическому типу (322,53 и 174,22 \% соответственно). Эти различия обусловлены состоянием нейрогенной регуляции, которая обеспечивает необходимый уровень тонуса микрососудов, и особенностями кровотока в микроциркуляторном русле.

Ключевые слова: капиллярный кровоток, лазерная допплеровская флуометрия (ЛДФ), параметр микроциркуляции, резистентность капиллярного кровотока, окклюзионная проба.

Stanishevska Tatiana, Gorna Oksana, Horban Darya. Peculiarities of Resistance Students' Capillary Blood Flow on Occlusion Test. The experimental research consisted of the study of blood microcirculation functional state by means of Laser Doppler flowmetry (LDF) method. It helped to evaluate the state of tissue blood-circulation and to reveal individual-typological peculiarities of blood microcirculation. 192 adolescent boys and girls, the students of Melitopol Bohdan Khmelnytskyi State Pedagogical University, aged 17-22, were examined. The obtained results showed that at most of students high-amplitude LDF was registered. According to LDF three types of blood microcirculation were revealed: normoemic, hyperemic, and hypoemic types. Resistance people` whom studied capillary blood flow on occlusion test depended on various types of blood microcirculation. Resistance students' capillary blood flow on occlusion test was the greatest at students with hypoemics' type of blood microcirculation, at students with hyperemics' and normoemics' types of blood microcirculation was much lower.

Key words: capillary blood flow, Laser Doppler flowmetry (LDF), option of microcirculation, resistance capillary blood flow, occlusion test.

Стаття надійшла до редколегії 18.09.2016 p.

УДК 612.1-057.874

\author{
Світлана Швайко, \\ Олена Дмитроца, \\ Юрій Трофим'як, \\ Олександр Журавльов
}

\title{
Адаптаційні можливості серцево-судинної системи дітей молодшого та середнього шкільного віку
}

Вивчено показники адаптаційних можливостей серцево-судинної системи дітей молодшого та середнього шкільного віку. У результаті дослідження встановлено, що в молодших школярів показники частоти серцевих

(С Швайко С., Дмитроича О., Трофим’як Ю., Журавльов О., 2016 
скорочень й артеріального тиску перебувають у межах вікової норми. У віковий період 7-9 років зафіксовано зниження частоти пульсу та підвищення артеріального тиску. За значеннями показників серцевого індексу відзначено перевагу симпатичної регуляції кровообігу, низьку витривалість і неекономну роботу серця обстежуваних молодшого шкільного віку. У підлітків частота серцевих скорочень зменшується, а артеріальний тиск підвищується, порівняно $з$ молодшим шкільним віком. За показниками витривалості роботи кровообігу та аеробними можливостями серцевої діяльності переважають учні середнього шкільного віку. Адаптаційні можливості в дітей і підлітків знижені, що пояснюється як віковими, так і фізіологічними особливостями розвитку організму.

Ключові слова: серцево-судинна система, адаптаційні можливості, молодший шкільний вік, середній шкільний вік

Постановка наукової проблеми та їі значення. У науковій літературі відзначено суттєве зростання захворюваності серед різних контингентів населення, спричинене сучасними умовами життя. Особливо несприятлива ситуація щодо цього серед дітей різного віку, що є найактуальнішою проблемою сьогодення. У низці досліджень зазначено, що майже 80 \% школярів України мають негативні тенденції в стані здоров'я, які набувають епідемічного характеру $[1 ; 5 ; 8 ; 10]$. Збереження здоров'я практично здорових людей - одне з нагальних завдань нашого суспільства [7; 9]. Наявність численних наукових досліджень у цьому напрямі підтверджує актуальність і багатопрофільність цієї проблеми [8; 10].

Загальновідомо, що одним із вагомих показників здоров'я людини є її здатність адаптуватися до факторів зовнішнього середовища. У сучасній літературі розвивається напрям, що грунтується на оцінці рівня здоров'я з погляду теорії адаптації. Адаптацію все частіше розглядають як інтегральний критерій здоров'я, що відображає ступінь його динамічної рівноваги із середовищем. Адаптація створює фон, який і визначає рівень здоров'я та ризик розвитку захворювань і залежить від вихідних резервних можливостей дитячого організму [8].

Здоров'я - здатність організму адаптуватися до умов зовнішнього середовища, а хвороба - зрив адаптації. Перехід від стану здоров'я до стану хвороби, зазвичай, пов'язаний зі зниженням адаптаційних можливостей організму. На думку дослідників, однією з причин незадовільного стану здоров'я $€$ значне погіршення адаптаційних можливостей дитячого організму, що призводить до втрати його здатності ефективно протистояти комплексу несприятливих чинників довкілля $[1 ; 4 ; 10]$.

На сьогодні проблема своєчасної та об'єктивної оцінки поточних адаптивних можливостей організму дітей шкільного віку - одна 3 найактуальніших питань загальної й вікової фізіології [2; 8$]$. Як указують численні фізіологічні дослідження, доведена можливість використання змін сукупності функціональних показників серцево-судинної системи як індикатора адаптивних реакцій цілісного організму $[3,8]$.

Аналіз дослідження цієї проблеми. Процеси адаптації організму на подразники зовнішнього середовища в різні періоди онтогенезу визначаються певною відповіддю функціональних систем. Для дітей і підлітків характерна гетерохронність процесів росту та розвитку, зумовлена біологічними й соціальними чинниками. Дитячий організм характеризується досить високою пластичністю та чутливістю до сприятливих і несприятливих факторів екзо- й ендогенного характеру, тобто саме адаптаційні можливості дитини забезпечують іiі існування в різноманітних умовах [9]. Отже, висока чутливість певних функцій до факторів зовнішнього середовища може бути використана для їх прогресивного розвитку й дає змогу контролювати вплив негативних чинників для попередження порушень функціонування організму [5; 9].

За даними авторів, в основі істотного погіршення функціонального стану дітей і підлітків лежить певний комплекс причин, серед яких провідна роль належить зниженню адаптаційних можливостей їхнього організму, що розвивається, та нездатністю до адекватної відповіді на несприятливі впливи зовнішнього середовища [5; 9].

Зважаючи на це, важливо відзначити, що провідне місце у формуванні оптимальної адаптивної реакції організму на зовнішні несприятливі впливи належить серцево-судинній системі $[1 ; 6]$. Отже, вивчення адаптивних можливостей апарату кровообігу школярів повинно зайняти провідне місце в комплексній проблемі морфофункціонального розвитку підростаючого покоління $[1 ; 6 ; 9]$. 
Зважаючи вищезазначені концепції, рівень функціонування серцево-судинної системи можна розглядати як провідний показник, що відображає рівновагу між організмом і середовищем. Рівень функціонування системи кровообігу є регульованою величиною, стабільність якої підтримується механізмами регуляції шляхом змін як міжсистемних, так і внутрішньосистемних взаємодій і взаємозв' язків. Не менш важливе завдання - розробка нових методів кількісної оцінки поточних адаптивних можливостей системи кровообігу у зв'язку зі значною роллю цього показника в системі оперативного контролю за загальним функціональним станом організму.

Актуальність і практичне значення вказаної проблеми - передумова для проведення нашого дослідження, спрямованого на вивчення особливостей адаптивних можливостей серцево-судинної системи організму дітей молодшого та середнього шкільного віку.

Мета й завдання статті. Мета дослідження - вивчення особливостей адаптаційних можливостей серцево-судинної системи дітей молодшого та середнього шкільного віку. Для їі досягнення перед нами поставлено завдання - здійснити порівняльний аналіз інтегральних показників функціонального стану роботи кровообігу молодших школярів та підлітків.

Матеріали та методи дослідження. Дослідження проведено на 60 школярах, здорових, праворуких, чоловічої й жіночої статей. Усіх обстежуваних розділяли на дві вікові групи (по 30 осіб): І група - молодшого (7-9 років), II - середнього (12-13 років) шкільного віку. Дослідження виконано 3 урахуванням міжнародних біоетичних стандартів про згоду батьків на участь дитини в комплексному обстеженні.

Для експрес-оцінки рівня адаптаційних можливостей серцево-судинної системи обстежуваних школярів використано комплекс морфофункціональних показників (частота серцевих скорочень (ЧСС, $y \partial . / x в)$, артеріальний тиск (АТд, АТс, мм рm.с m.), пульсовий тиск (АТп, мм pm. cm.), середній гемодинамічний тиск (СГТ, мм pm. cm.)) та індексів (індекс Кердо (IК, ум. од.), коефіцієнт економізації кровообігу (КЕК, ум. од.), коефіцієнт витривалості за формолою Кваса (КВ, \%), індекс Робінсона (ІРб, ум. од.), адаптційний потенціал за методикою Р. Баєвського (АП, ум. од.)). Указані показники мають найвищий ступінь взаємозв' язку з енергозабезпеченністю організму, рівнем загальної витривалості та захворюваністю (адаптаційний потенціал) [2; 6; 10].

Під час оброки отриманих даних використовували загальноприйняті методи варіаційної статистики з використанням критерію Стьюдента.

Виклад основного матеріалу й обгрунтування отриманих результатів. Отримані в ході дослідження показники частоти серцевих скорочень (ЧСС) характеризувалися підвищеними значеннями відносно вікової норми в обстежуваних семи та 13 років, що вказує на незначне напруження регуляторних механізмів роботи кровообігу в молодших школярів (рис. 1).

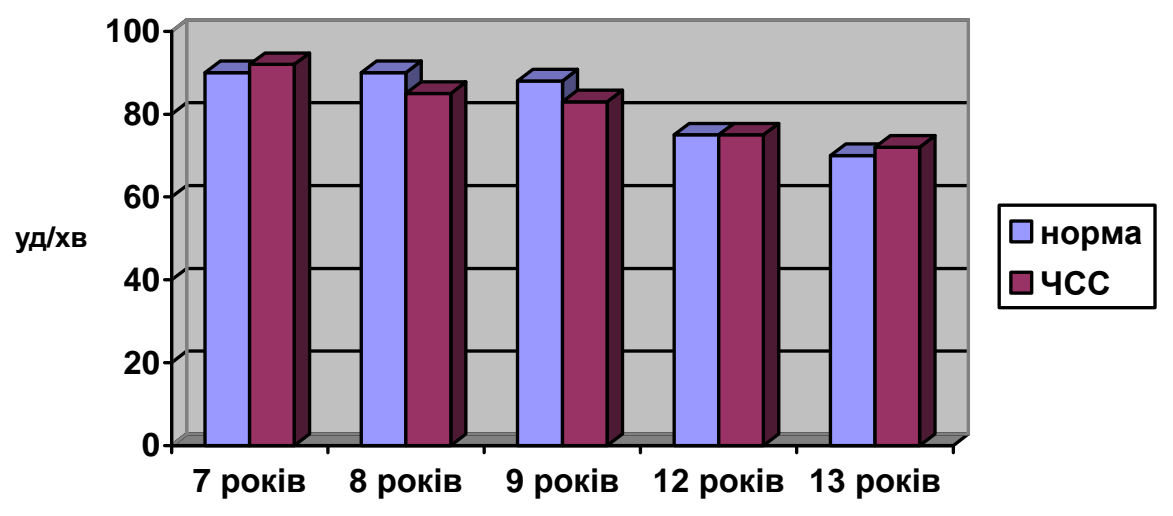

Рис. 1. Показники частоти серцевих скорочень (ЧСС, уд./хв) обстежуваних

Показники артеріального тиску (АТ) характеризувалися достовірно нижчими значеннями відносно вікової норми в обстежуваних підліткового віку (рис. 2).

На основі отриманих даних показників АТ установлено їхні статеві відмінності в підлітковому віці: у дівчат указані показники є нижчими. 


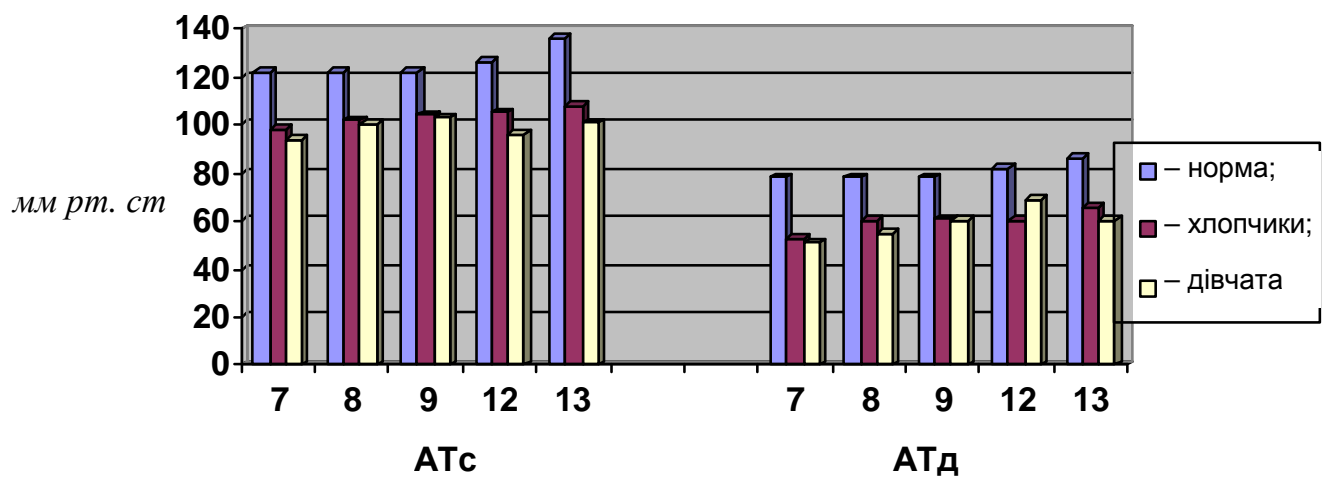

Рис. 2. Показники артеріального тиску (ATc, АTд, мм рт. ст.) обстежуваних різного віку

Показники середнього гемодинамічного тиску (СГТ) указують на його підвищення з віком, а також на вищі його значення в хлопців, порівняно $з$ дівчатами; достовірну відмінність зафіксовано в 13 років (рис. 3 ).

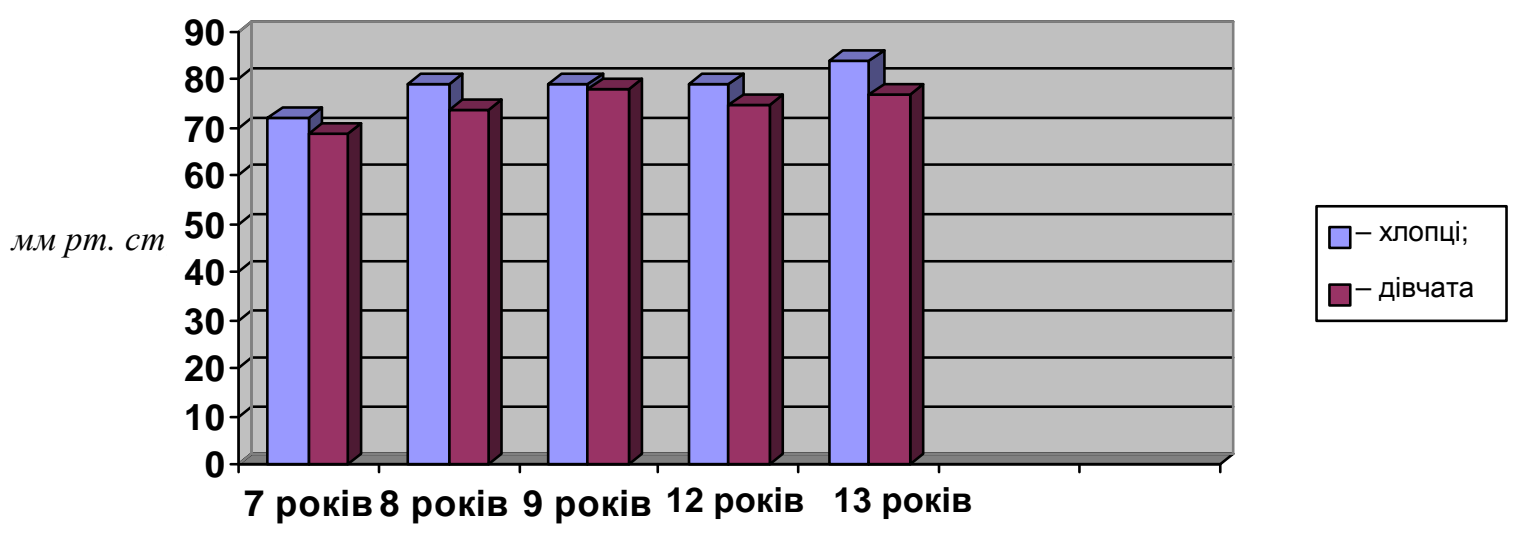

Рис. 3. Показники середнього гемодинамічного тиску (СГТ, мм рт. ст.) обстежуваних

Рівень адаптаційних резервів серцево-судинної системи (ССC) молодших школярів та підлітків визначали на основі розрахунку серцевих індексів, що вказують на особливості адаптаційних можливостей серцево-судинної системи та цілого організму.

За показниками коефіцієнта витривалості (КВ, нормативний показник - $16 \%$ ), у наших дослідженнях показано, що в усіх вікових групах указаний індекс $\epsilon$ вищим за норму, незалежно від статі (рис. 4). Потрібно зазначити, що хлопці 2-13 років характеризувалися КВ, що більше наближався

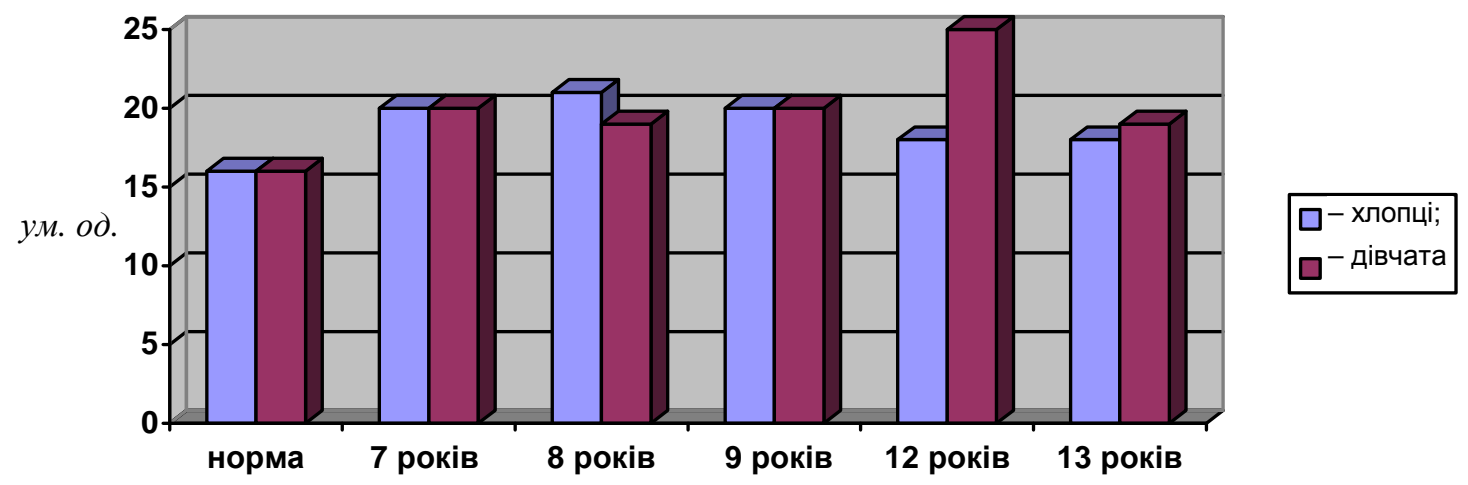

Рис. 4. Показники коефійієнта витривалості (КВ, \%) сериеево-судинної системи обстежуваних 
до його нормативних значень. У той час дівчата 12 років за визначеними показниками КВ характеризуються утрудненою витривалістю роботи ССС, на що вказують їхні достовірно вищі значення.

За результатами аналізу показників вегетативного індексу Кердо (ВIК), що характеризує стан регуляції ССС із боку симпатичної та парасимпатичної систем, нами простежено суттєву перевагу симпатичного відділу нервової системи в дітей молодшого шкільного віку (рис. 5). У підлітків 12-13 років вплив симпатичної нервової системи ще присутній, проте в хлопчиків 13 років перевага цієї системи $\epsilon$ незначною. Аналіз результатів ВІК свідчить про зменшення впливів симпатичної нервової системи з віком, що підтверджується іншими дослідниками [2]. Отже, із 13 років бачимо перевагу парасимпатичної системи в регуляції серця.

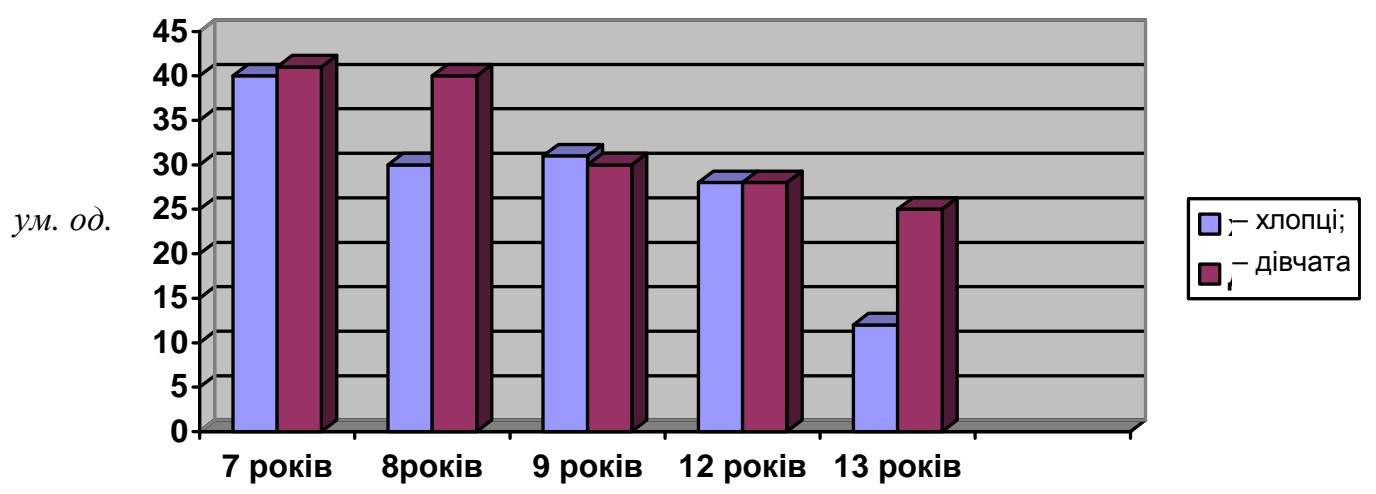

Рис. 5. Показники вегетативного індексу Кердо (ВIК, ум. од.) обстежуваних

Для визначення резервно-функціональних можливостей кардіоваскулярної системи обстежуваних використовували індекс Робінсона (IPб). Аналіз значень цього показника вказує на покращену (відповідає середньому рівневі) систолічну роботу серця та аеробні можливості організму в 13-річних хлопців і 12-річних дівчат; ця особливість є достовірною (рис. 6).

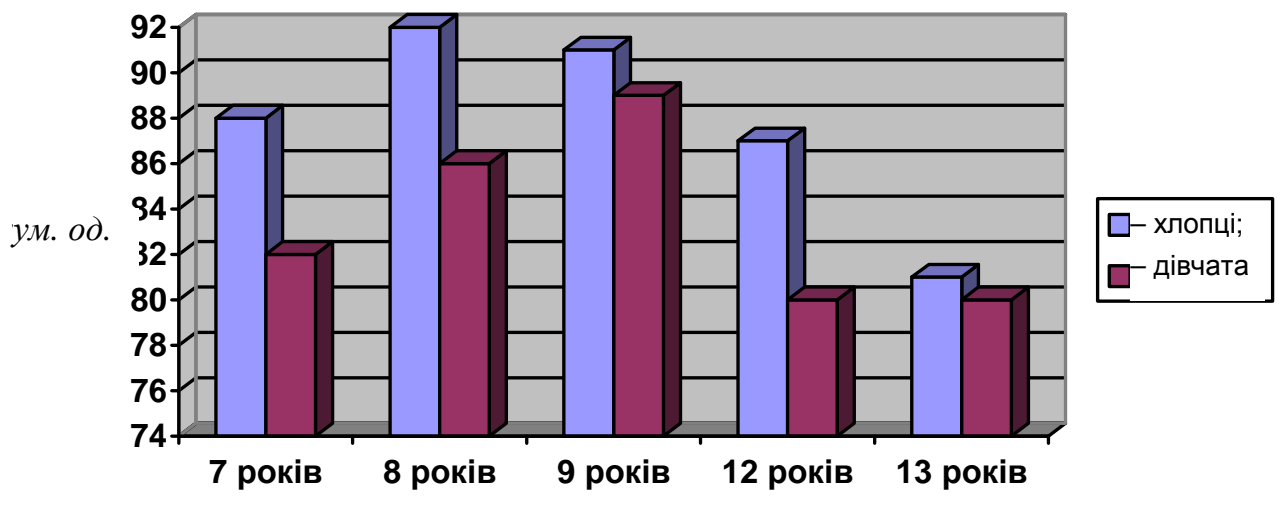

Рис. 6. Показники індексу Робінсона (ІРб, ум. од.) обстежуваних

За визначеними показниками коефіцієнта економічності кровообігу (КЕК) установлено, що в молодшому шкільному віці робота ССС $\epsilon$ неекономною. У підлітків 12-13 років економніше використовуються резерви кровообігу; ця особливість більше стосується дівчат 12-13 років і хлопців 13 років (рис. 7 ).

Здатність до адаптації залежить не лише від наявних функціональних резервів, а й від адекватності та економічності реагування, а також від ефективності управління процесами витрачання й відновлювання резервів. Отримані дані вказують на те, що з віком покращується витривалість ССС. У підлітків-хлопців найкраща витривалість серця (за коефіцієнтом витривалості), порівняно з молодшими школярами та дівчатками підліткового віку. Систолічна робота серця, аеробні можливості, а також економність роботи ССС вища у підлітковому віці. За показниками серцевих індексів адаптаційні можливості дітей молодшого віку є зниженими. 


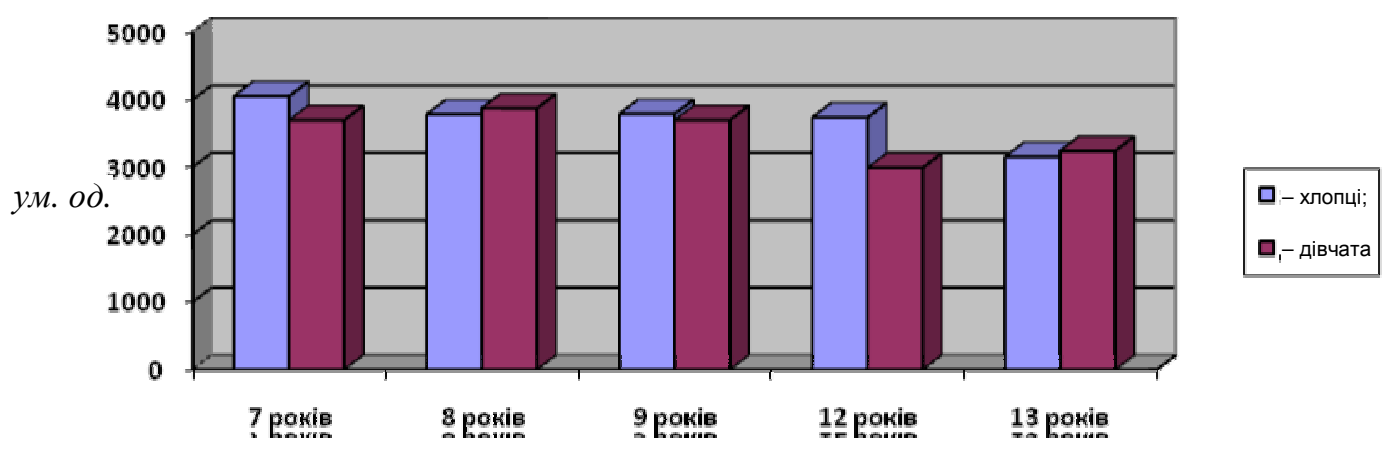

Рис. 7. Показники коефіиієнта економічності кровообігу (КЕК) обстежуваних

Для уточнення даних серцевих індексів, які визначають рівень функціональних можливостей організму, визначали адаптаційний потенціал (АП), ураховуючи індивідуальні показники кожного школяра (ріст, масу та вік). За отриманими даними встановлено, що серед дітей 7-8 років найвища частка осіб, які мають напругу механізмів адаптації й незадовільну адаптацію організму, тоді як серед 9-річних школярів зафіксовано найвищий відсоток дітей, котрі характеризуються зривом адаптаційних можливостей (рис. 8).

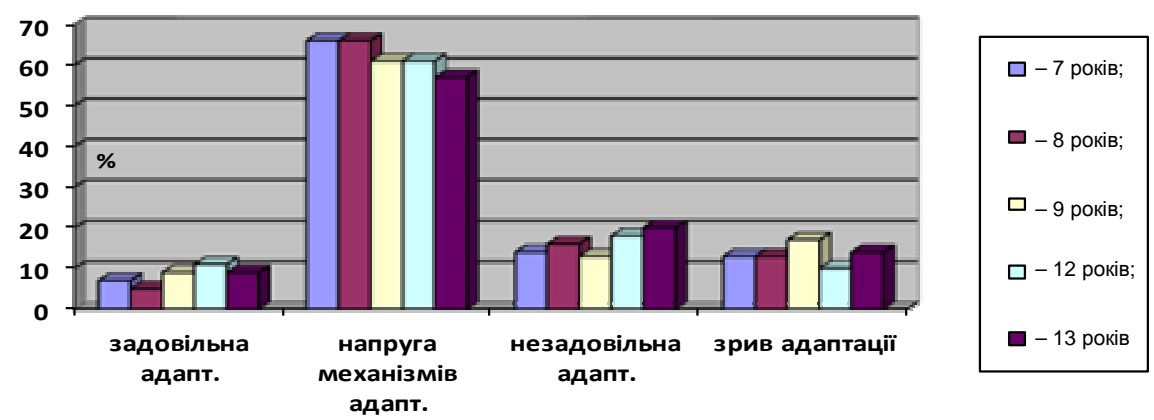

Рис. 8. Розподіл обстежуваних школярів за рівнем адаптаційних можливостей організму

Зниження адаптаційних можливостей у вказані вікові періоди, можливо, пов'язане 3 недостатньою зрілістю серцево-судинної системи та віковими особливостями організму. За результатами показників АП виявлено, що більшість дітей молодшого шкільного віку (66 \%) мають напружений його рівень, тобто перебувають у донозологічному стані. Потрібно зазначити, що кількість хлопців із напруженим механізмом адаптації перевищує кількість дівчаток у всіх вікових групах; ця особливість, пояснюється статевими закономірностями розвитку організму [4; 6].

У 12-річному віці простежено найвищу частку дітей із задовільною адаптацією. Водночас у цьому віці найбільший відсоток дітей із незадовільною адаптацією та зі зривом адаптації. Очевидно, це пов'язано 3 тим, що середній шкільний вік збігається 3 критичним періодом розвитку дитини, тому регуляторні механізми серцево-судинної системи неефективно й неекономічно адаптують дітей до змін навколишнього середовища.

Висновки. У дітей молодшого шкільного віку частота серцевих скорочень та артеріальний тиск перебувають у межах вікової норми. Показники частоти пульсу знижуються, а артеріального тиску підвищуються від семи до дев'яти років. Серцеві індекси вказують на перевагу симпатичної регуляції кровообігу, низьку витривалість та неекономну роботу серця в молодших школярів. У підлітковому віці частота серцевих скорочень зменшується, а артеріальний тиск підвищується, порівняно з молодшим шкільним віком. Більшою витривалістю та кращими аеробними можливостями серцевої діяльності характеризуються учні середнього шкільного віку. Адаптаційні можливості в дітей і підлітків знижені, що пояснюється як віковими, так і фізіологічними особливостями розвитку організму. 
У перспективі планується проведення комплексного дослідження адаптаційних можливостей серцево-судинної системи школярів, залежно від впливу природних факторів місця проживання.

\section{Джерела та література}

1. Апанасенко Г. Л. Индивидуальное здоровье: в поисках сущности и критериев количественной оценки / Г. Л. Апанасенко // Довкілля та здоров’я. - 2015. - № 3. - С. 8-12.

2. Антропова М. В. Прогностическая значимость адаптационного потенциала сердечно-сосудистой системы у детей 10-11 лет / М. В. Антропова, Г. В. Бородкина, Л. М. Кузнєцова [и др.] // Физиология человека, 2000. - Т. 26, № 1.- С. 56-61.

3. Баевский Р. М. Прогнозирование состояний на грани нормы и патологии / Р. М. Баевский. - М. : Медицина, 1999. - 230 с.

4. Богдановська Н. В. Динаміка адаптивних можливостей організму дітей шкільного віку протягом навчального року / Н. В. Богдановська, Ю. Б. Бойченко // Вісник Запорізького національного університету. Фізичне виховання та спорт. - 2014. - № 1. - С. 112-120.

5. Завада М. Т. Оцінка стану здоров’я дітей та підлітків Львівської області / М. І. Завада // Довкілля та здоров’я. - 2016. - № 2. - С. $59-62$.

6. Квашніна Л. В. Особливості адаптації серцево-судинної системи до систематичного навчання та методи корекції ії порушень у дітей молодшого шкільного віку / Л. В. Квашніна, В. П. Родіонов, Ю. Ф. Маковкіна, Т. Б. Ігнатова, В. В. Матвійчук // Перинатология и педиатрия. - № 4 (36). - 2008 - С. 7-11.

7. Лучишин Н. Ю. Адаптація і здоров’я організованих дітей дошкільного віку / Н. Ю. Лучишин // Современная педиатрия. - 2009. - № 6. - С. 91-94.

8. Няньковський С. Л. Медико-соціальні особливості стану здоров’я / школярів та Львівської області / С. Л. Няньковський, М. С. Яцула, О. М. Сенкевич [та ін.] // Львівський клінічний вісник. - № 3 (3). 2013. - C. 31-35.

9. Охапкіна О. В. Особливості адаптаційних механізмів організму дітей з малими аномаліями розвитку серця / О. В. Охапкіна // Здоровье ребенка. - 2013. - № 3. - С. 41-43.

10. Полька Н.С. Проблеми збереження довкілля і здоров’я нації у матеріалах XV з'їзду гігієністів України / Н. С. Полька, В. І. Федоренко, Б. А. Пластунов // Довкілля та здоров’я. - 2013. - № 2. - С. 68-80.

Швайко Светлана, Дмитроца Елена, Трофимьяк Юрий, Журавлёв Александр. Адаптационные возможности сердечно-сосудистой системы детей младшего и среднего школьного возраста. Изучены показатели адаптационных возможностей сердечно-сосудистой системы детей младшего и среднего школьного возраста. В итоге исследования установлено, что у младших школьников показатели частоты сердечных сокращений и артериального давления находятся в пределах возрастной нормы. В возрастной период 7-9 лет зафиксировано снижение частоты пульса и повышение артериального давления. По значениям показателей сердечного индекса отмечаются преобладание сематической регуляции кровообращения, низкая выносливость и неэкономная работа сердца исследуемых младшего школьного возраста. В подростков частота сердечных сокращений снижается, а артериальное давление повышается, по сравнению с младшим школьным возрастом За показателями выносливости работы кровообращения и аэробными возможностями сердечной деятельности преобладают ученики среднего школьного возраста. Адаптационные возможности у детей и подростков снижены, что объясняется как возрастными, так и физиологическими особенностями развития организма.

Ключевые слова: сердечно-сосудистая система, адаптационные возможности младший школьный возраст, средний школьный возраст.

Shvayko Svitlana, Dmytrotsa Olena, Trofymiak Yurii, Zhuravlov Oleksandr. Adaptive Capacity of Cardiovascular System of Primary and Secondary School age Children. Indicators of adaptive capacity of the cardiovascular system of primary and secondary school age children are studied. The research proved that indicators of primary pupils' heart rate and blood pressure are within the age norm. It is recorded that at the age from 7 to 9 heart rate decreases and blood pressure increases. By cardiac index values superiority of sympathetic regulation of blood circulation, low endurance and wasteful heart function of examined primary school age children were marked. Teenagers' heart rate decreases and blood pressure increases compared to primary school age pupils. Pupils of secondary school age predominate in terms of endurance of blood circulation and aerobic capability of cardiac capability. Children's and teenagers' adaptive capacity is reduced, due to both age and physiological characteristics of the organism development.

Key words: cardiovascular system, adaptive capacity, primary school age, secondary school age.

Стаття надійшла до редколегії 06.09.2016 р. 